\title{
The Bounty's Primogeniture and the Thursday-Friday Conundrum
}

\author{
By Donald Albert*
}

\begin{abstract}
This is a biography of an obscure individual born of the ashes of the H.M.A.S. Bounty on the remote, inaccessible, and uninhabited Pitcairn Island in 1790. Thursday October Christian is best known to amateur and professional historians, philatelists, and others interested in the romance and adventure of the South Seas. He was eighteen years old when he first had contact with the outside world with the arrival of the American sealer Mayhew Folger of the Topaz in 1808. In the forty years of his life he would meet, greet, and otherwise interact with sealers, whalers, naval officers, traders, and others calling on Pitcairn. This article synthesizes these disparate encounters while exploring a name change conundrum revolving around the protagonist. Thursday October Christian was an ordinary person whose life story now lingers in disparate reports, notices, and accounts of archived and otherwise rare documents.
\end{abstract}

\section{Introduction}

On 28 April 1789 Fletcher Christian mutinied against Lieutenant Bligh, commander of the Bounty. Fletcher forced Bligh and eighteen crew into the Bounty's launch around Tofua. Miraculously, Bligh sailed almost 6,000 kilometers to the Dutch settlement of Coupang, Timor. Fletcher and the mutineers, eventually (January 1790) encountered the mischarted, remote, and wave-inundated cliffs of Pitcairn Island $\left(25^{\circ} 04^{\prime} \mathrm{S}, 130^{\circ} 06^{\prime} \mathrm{W}\right)$ in the South Pacific Ocean (Figure 1). ${ }^{1}$ Fletcher Christian located Pitcairn Island even though his source had it located $342 \mathrm{~km}$ west from its actual location. ${ }^{2}$ The

*Professor, Sam Houston State University, USA.

1. Caroline Alexander, The Bounty: The True Story of the Mutiny on the Bounty (New York: Viking, 2003); Robert Kirk, Pitcairn Island, the Bounty Mutineers and Their Descendants: A History (Jefferson, N.C.: McFarland \& Co, 2008); Sven Wahlroos, Mutiny and Romance in the South Seas: A Companion to the Bounty Adventure (iUniverse.com, Inc., 2001); Spencer Murray, Pitcairn Island: The First 2000 Years (La Canada, CA: Bounty Sagas, 1992); Richard Hough, Captain Bligh \& Mr. Christian: The Men and the Mutiny (New York, E.P.: Dutton, 1973).

2. John, Hawkesworth et al., An Account of the Voyages Undertaken by the Order of His Present Majesty for Making Discoveries in the Southern Hemisphere, and Successively Performed by Commodore Byron, Captain Wallis, Captain Carteret, and Captain Cook, in the Dolphin, the Swallow, and the Endeavour: Drawn Up from the Journals Which Were Kept by the Several Commanders, and from the Papers of Joseph Banks, Esq. (London: Printed for W. Strahan and T. Cadell in the Strand, 1773); Donald Patrick Albert, "Did or Could Seabirds 'Halo' Pitcairn Island for Fletcher Christian?" Terrae Incognitae 50, no. 2 (2018): 99-114. 
mutineers and their Polynesian consorts experienced tumultuous early years with deaths from accidents and murders, until settling down under the tutelage of the sole male survivor John Adams (aka Alexander Smith) around 1800. Fletcher's son, Thursday October, though born into infamy on the inconsequential and isolated mutineers' settlement of Pitcairn Island, entertained, guided, and hosted seafaring visitors from far and away.

It is unknown why Fletcher Christian named his son Thursday October Christian. Glynn Christian suggested that naming a child after the day and month of birth was a common form of protest among West Indian slaves. ${ }^{3}$ Most accounts place the month and year of his birth as October 1790; however, Ian Ball speculated that Thursday might have been born on board the Bounty in 1789.4 However, The Pitcairn Island Register Book contains several entries on Thursday October Christian, including his birth on the island during October $1790 .{ }^{5}$

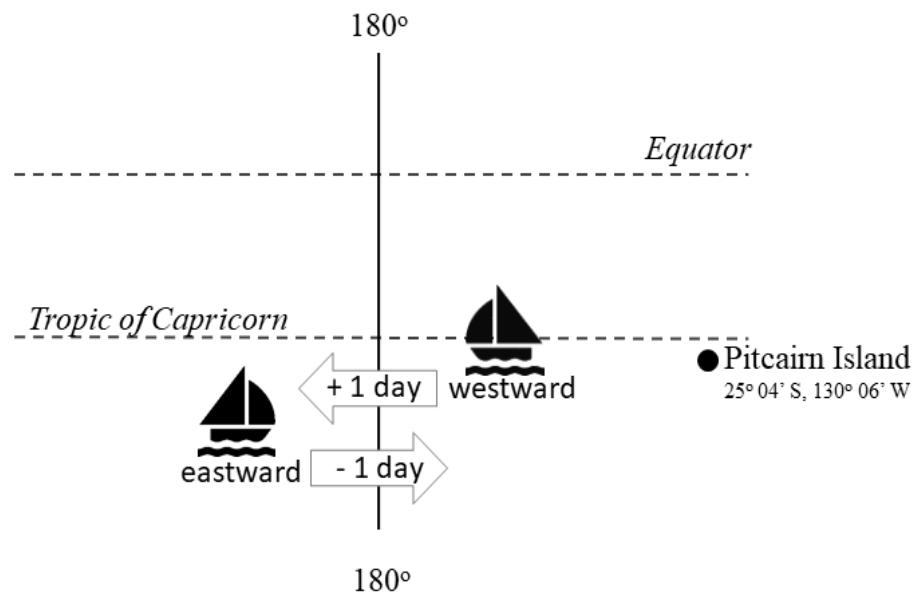

Figure 1. Pitcairn Island, South Pacific: Map Reference and Date Line Crossing Mechanics

\section{Life Events and Visitors}

Thursday October Christian was the son of Fletcher Christian and a fullblooded Tahitian named Mauatua (Isabella); he had two siblings, Charles and Mary Ann. ${ }^{6}$ Thursday was almost three years old when his father succumbed

3. Glynn Christian, Fragile Paradise: The Discovery of Fletcher Christian, Bounty Mutineer (United States: Bounty Books, 2005), 247.

4. Ian M. Ball, Pitcairn: Children of Mutiny (Boston: Little Brown, 1973), 113.

5. Charles Prestwood Lucas, The Pitcairn Island Register Book (London: Society for Promoting Christian Knowledge, 1929), 8.

6. Donald Albert, "Charles Christian and His Contributions to Pitcairn History," The Pitcairn Log 46, no. 2 (April 2019): 8-10. 
as "some natives proceeded to shoot Christian; they found him clearing some ground for a garden."7 The next event is his marriage to Susannah in 1806, a full-blooded Tahitian and much older; he was around sixteen and she over thirty. The Register lists the birth of six children (Charles, Joseph, Mary, Polly, and Peggy), including a son born in 1820 whom he called "Thursday O. Christian," that is, the II.

Thursday October Christian entered the picture at aged 18 and 24 years, respectively, on the arrival of the Topaz (1808) and Briton and Tagus (1814). Mayhew Folger's rediscovery of Pitcairn Island in 1808 finds "three young men in a double canoe" paddling toward the Topaz. ${ }^{9}$ Presumably, one of these men was Thursday October Christian, at least according to Hough. ${ }^{10}$ Several accounts reiterate his physical appearance with "tall" reappearing more than once. ${ }^{11}$ Six years later, the British Captain Pipon of the Tagus described Thursday October Christian as about six feet tall, "brown cast," with dark, deep black hair, again wearing the loincloth, hat with feathers, and "occasionally a Pauncho."12 John Bechervaise of the Blossom, during a December 1825 visit, noted that Thursday was agile and powerful. ${ }^{13}$ The only depiction of the first-born is a sketch by Lieutenant Shillibeer during an 1814 visit of the H.M.S. Briton (Figure 2). ${ }^{14}$ Curiously, Lieutenant Shillibeer titled this portrait "Friday Fletcher October Christian."

7. See Appendix E: Jenny's Story (1829) reprinted from the United Services Journal and Naval and Military Magazine, 1829, Part II, 589-593 in William Bligh and Edward Christian, The Bounty Mutiny (New York: Penguin Books, 2001), 231.

8. Amasa Delano, A Narrative of Voyages and Travels, in the Northern and Southern Hemispheres: Comprising Three Voyages Round the World, Together with a Voyage of Survey and Discovery, in the Pacific Ocean and Oriental Islands (Boston: Printed by E. G. House, for the author, 1817), 126-131.

9. Bligh and Christian, The Bounty Mutiny, Appendix D, 215-227; Appendix D includes letters from Folger and Staines on encounters with Pitcairn Islanders published in The Quarterly Review 13 (1815): 374-383.

10. Hough, Captain Bligh \& Mr. Christian, 271.

11. Harry L. Shapiro, The Heritage of the Bounty: The Story of Pitcairn Through Six Generations (New York: Simon and Schuster, 1936), 72; Hough, Captain Bligh \& Mr. Christian, 271.

12. Rosalind Amelia Young, Mutiny of the Bounty and Story of Pitcairn Island, 17901894 (Oakland: Pacific Press Pub. Co., 1894), 42.

13. John Bechervaise, Thirty-Six Years of a Seafaring Life (Portsea, England: W. Woodward, 1839), 169-170.

14. John Shillibeer, A Narrative of the Briton's Voyage to Pitcairn's Island (London: Law and Whittaker, 1817). 


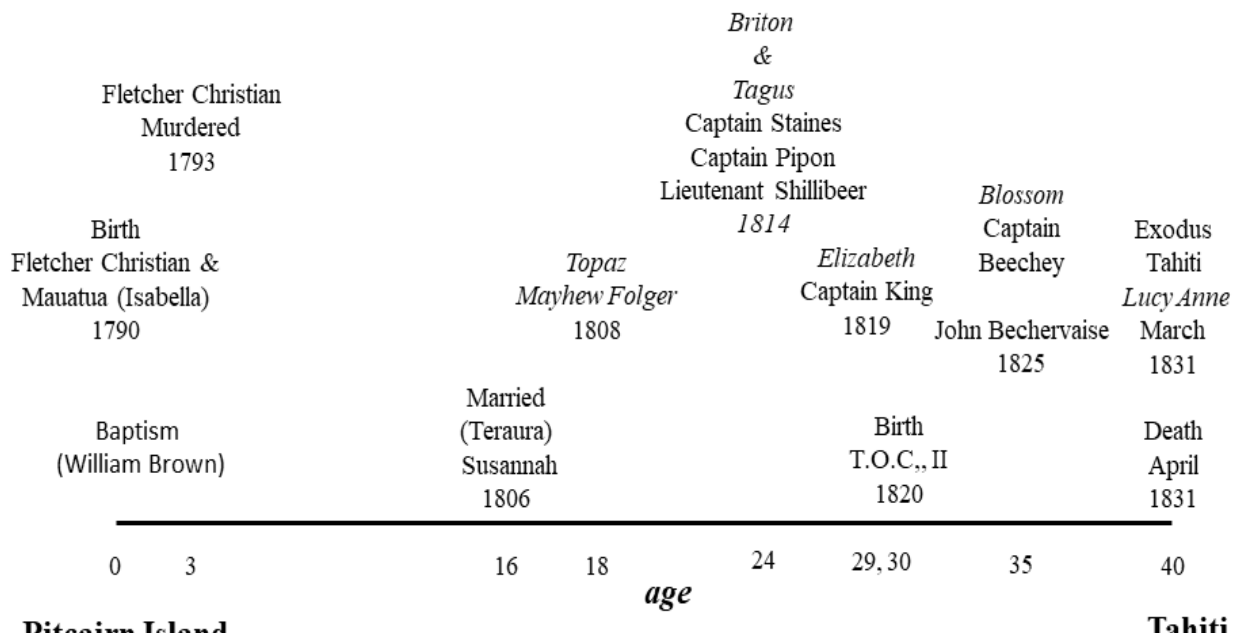

Pitcairn Island

Tahiti

Figure 2. Life Events: Thursday October Christian, 1790-1831

While it is arguable that present-day authors can surmise an accurate persona from scouring the archives, there are numerous impressions of Thursday's interactions with his contemporaries that provide insight into his demeanor. He must have been an intrepid paddler being able to navigate the treacherous surf to greet Folger (1808), and later Staines and Pipon (1814). Pipon wrote that Thursday spoke English "in a manner vastly pleasing." $15 \mathrm{He}$ appears to have been generous with one account finding him offering a present of "some fruit and a hog"16 and another noting his hospitable, good humored and obliging nature. ${ }^{17}$ On bringing "refreshments" through the surf, Pipon observed that Thursday was a "most active and expert swimmer."18

On board the Briton, two observations recorded by Lieutenant Shillibeer offer another glimpse of Thursday's psyche. The first described Thursday as saying grace before and after meals; this stemmed from a conservative and devote Christian faith prescribed by John Adams. The second, his uneasiness when a black servant entered the gunroom. Thursday rose, and said, "I don't like that black fellow, I must go."19 Being in an unfamiliar situation, Thursday's reaction projects fear rather than prejudice. ${ }^{20}$ Whether his attitude towards

15. Philip Pipon, Capt Pipon's Narrative of the State Mutineers of H. M. Ship Bounty Settled on Pitcairn's Island in the South Sea. Retrieved from https://bit.ly/2115TBG.

16. See Appendix D: "The Quarterly Review on the Bounty" (1815) reprinted in Bligh and Christian, The Bounty Mutiny, 215-227.

17. Pipon, Capt Pipon's Narrative of the State Mutineers.

18. Pipon, "The Descendants of the Bounty's Crew: As First Discovered by the Briton and Tagus Frigates. - From the Unpublished Mss. of the Late Capt. Pipon, R.N.," The United Service Journal (1834), Pt. 1: 197.

19. Shillibeer, A Narrative of the Briton's Voyage, 89.

20. The suggestion that Thursday's reaction might have been attributed to fear rather than a racist prejudice came from an anonymous reviewer. 
"blacks" changed during the remaining sixteen years of his life is unknown to the author.

American captain Henry King of the Elizabeth mentioned a feast given at Thursday's house on a visit 3 March 1819. Captain King witnessed the islanders performing grace before and after dinner, individually beginning with the most senior. The menu included a suckling pig, two fowls, yams, plantains, bananas, and a "species of apple peculiar to the island."21 Six years later, December 1825, English Captain Beechey of the H. M. sloop Blossom attended a dinner hosted by Thursday. Beechey found a table complete with an incongruous setting of plates, knives, and forks, which he described as "an unexpected sight" given their isolation and remoteness..$^{22}$ During the Blossom's visit from 5-21 December 1825, Thursday demonstrated his athletic and agile nature. ${ }^{23} \mathrm{He}$ impressed Beechey as a perceptive guide with the ability to hear faint signals sent from across the island. ${ }^{24}$ At thirty-five years, he was still a vigorous individual able to run down wild goats, at least on level ground. Bechervaise of the Blossom recounts: "During my stay I saw October Christian and young Adams run down several, which were sent as presents to the seaman of the B." 25 Through all these encounters, beginning with Folger (Topaz, 1808) and continuing with Captain Staines, Captain Pipon and Lieutenant Shillibeer (Tagus and Briton, 1814), Captain King (Elizabeth, 1819), and then Captain Beechey (Blossom, 1825), Thursday's thoughtful, hospitable and an outwardly religious manner were manifest during his numerous encounters with those visitors (Figure 3). ${ }^{26}$

21. "Extract from the Journal of Captain Henry King of the Elizabeth," The Edinburgh Philosophical Journal 3, no. 6 (Oct. 1820): 380-388.

22. Frederick W. Beechey, Narrative of A Voyage To The Pacific And Beering's Strait, To Co-Operate With The Polar Expeditions: Performed In His Majesty's Ship Blossom, Under The Command Of Captain F. W. Beechey, R. N. In The Years 1825, 26, 27, 28, vol. 1 (London: Henry Colburn and Richard Bentley, 1831), 101.

23. Trevor Lummis, Life and Death in Eden: Pitcairn Island and the Bounty Mutineers (London: Phoenix, 2000), 92.

24. Beechey, Narrative of A Voyage, 110-111.

25. Bechervaise, Thirty-six Years of a Seafaring Life, 173.

26. Shillibeer, Narrative of the Briton's Voyage, 82. Shillbeer used Friday even though Captain Staines on same visit reported Thursday. 


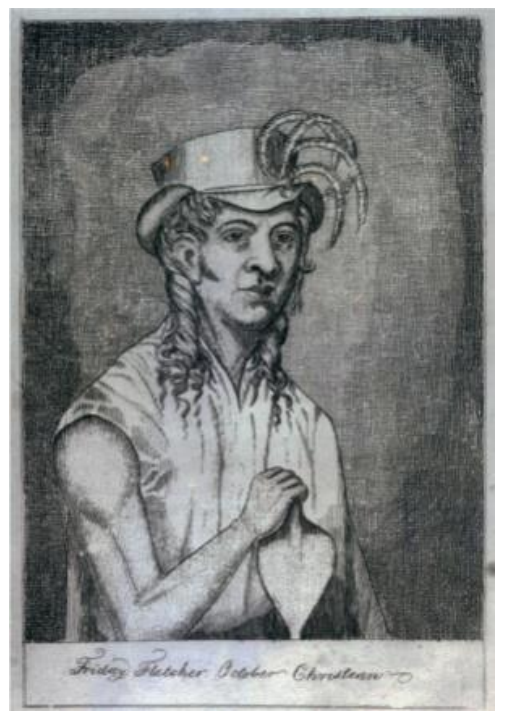

Figure 3. Shillibeer's Sketch of Thursday October Christian, 1814 Source: Shillibeer, 1817, image between pages 96-97.

Fears that limited resources could support a growing population, especially during a prolonged drought, "could dry up the unreliable springs for good, shrivel garden crops upon which so much depended, and empty storage basins of drinking water." 27 Thursday October Christian, along with his namesake Thursday October the II, were among the roll of Pitcairn Islanders transported to Tahiti on the Lucy Anne in March 1831.28 Thursday October Christian died on 21 April 1831, within one month of immigrating to Tahiti to an epidemic infectious disease (Figure 3). In two groups the islanders returned to Pitcairn Island with one smaller group arriving on 27 June 1831, and a larger group on 4 September 1831, respectively. Sixteen or one-fifth of the islanders population died from April to November as a result of this failed immigration attempt. ${ }^{29}$

The archives support the supposition that Bounty's primogeniture was an exceptional human specimen confident in his abilities to interact with the wild waves and sheer cliffs that encase Pitcairn Island. His willingness to greet passing vessels indicates an articulate nature useful in communicating with strangers. The archives are replete with accounts of his helpfulness and generosity towards visitors. Though he might have been ignorant with respect to education and perhaps leadership potential, his personality exuded positive qualities that were a benefit to his family, friends, the Pitcairn community, and visitors too.

27. Murray, Pitcairn Island: The First 2000 Years, 78-79.

28. Walter Brodie, Pitcairn's Island, and the Islanders in 1850 (London: Whittaker \& Co., 1851), 72.

29. Kirk, Pitcairn Island, 80-81. 


\section{Name Change Confusion}

Ian Ball referred to the first born as "Friday (soon to be Thursday)." He quotes Warren Clive Christian (1914-2003) stating that "Fletcher get Friday October, who we later called Thursday, and Friday/Thursday get Thursday October the Second." 30 One of the most intriguing paragraphs from Pitcairn: Children of Mutiny provides Ball's interpretation of this name-change conundrum:

On the day he came into the world, his father made a simple calendar error. The boy was first Friday October and continued to be known by that name until the skipper of the Topaz came ashore in 1808 and informed the islanders that, while their chronometer from the Bounty was still accurate and they had kept meticulous track of the days, months, and years, Fletcher had slipped up on one basic point. After deposing Bligh, and while the mutineers were sailing back to Tahiti, Fletcher forgot to record that they had crossed the International Date Line. His first son was born on a day the Pitcairn colonists observed as Friday. Actually, east of the Date Line, it was Thursday. Friday October thanked Captain Folger for pointing out this error, and henceforth was known as Thursday October. ${ }^{31}$

The Guide to Pitcairn, ${ }^{32}$ claims that Thursday October Christian was "Born in October 1790...was also known as Friday October Christian after 1814 when time was corrected." This quote gives the year 1814 and reason as a "time adjustment" for the change from Thursday to Friday. Further, the "also known as" suggests that both names were acceptable, that one did not negate the other. Allen Frost puts forth a reasonable argument for Friday first in his Mutiny, Mayhem, Methodology: Bounty's Enigmatic Voyage. He notes two eyewitness accounts (see Shillibeer and Jenny) referring to the protagonist as Friday. Further, Frost points to a trail on Pitcairn Island known to the islanders "into the 1970s" as Friday Road. ${ }^{33}$ While not conclusive, Frost at least provided anecdotal evidence to consider. ${ }^{34}$ However, most accounts, including Shapiro's, mention even if parenthetically, a name change: "The eldest was Thursday (Friday in the island records) October Christian, then eighteen years old and already a tall, powerfully built man."35

30. Ball, Pitcairn: Children of Mutiny, 179.

31. Ibid., 114.

32. Guide to Pitcairn (Adamstown, Pitcairn Island: Government of Pitcairn Island's Tourism Department, 2013), 14.

33. Alan Frost, Mutiny, Mayhem, Methodology: Bounty's Enigmatic Voyage (Sydney: Sydney University Press, 2018), 142-143.

34. Dening also supports the Friday to Thursday name change, see, Greg Dening, Mr Bligh's Bad Language: Passion, Power, and Theatre on the Bounty (Cambridge, England: Cambridge University Press, 1992).

35. Shapiro, The Heritage of the Bounty, 36. 
Vol. 7, No. 2 Albert: The Bounty's Primogeniture and the Thursday-Friday...

\section{Name Change in Context of International Date Line}

Antonio Pigafetta, a survivor of Magellan's westward sailing global circumnavigation (1519-1522), provided proof positive the need for calendar adjustment on returning from such a journey. To Pigafetta's amazement, he thought it Wednesday, but to the Portuguese it was Thursday. ${ }^{36}$ Thereafter, the Spanish demarcated a date line encapsulating the Philippines, placing it on the same date as South America. In the 1800s with Spanish colonialism waning in South America, the Philippine Adjustment (1845) repositioned its date line to align with Spain.

The International Date Line traces its inception, at least nominally, to the International Meridian Conference that convened in Washington, DC in 1884. ${ }^{37}$ Here the delegates chose Greenwich as the Prime Meridian; 180 degrees away an empty ocean scattered with isolated islands provided an ideal region to first start the day, hence the International Date Line (IDL). In an east-west crossing the calendar increases one day, for example, Thursday advances to Friday; whereas, a west-east crossing the calendar decreases one day, Friday retreats to Thursday (Figure 1). The IDL operates under de facto rather than de jure status; hence, adjustments represent unilateral decisions of the involved countries. ${ }^{38}$ The English, and even the French, maintained home dates during their exploration and colonization of the Pacific, and this is evident in examining the logs of Lieutenant Bligh. This problem of reckoning dates in Polynesia persisted into $19^{\text {th }}$ century until even after the de facto recognition of the International Date Line in 1884. This generated Sabbath mismatches between indigenous residents (local) and their European visitors (British, French) with adjacent Sundays co-existing across the Society Islands (Tahitian Sabbath) and elsewhere..$^{39}$

\section{Thursday or Friday?}

Most accounts, including letters and extracts from Captains Pipon, Staines, Henderson, and King, report Thursday as the original name. For official documents, Thursday occurs in the Pitcairn Island Register Book and on the Lucy Anne's passenger list of emigrants to Tahiti. Just a few eyewitness

36. Laurence Bergreen, Over the Edge of the World: Magellan's Terrifying Circumnavigation of the Globe (New York: Morrow, 2003).

37. Dava Sobel, Longitude (New York: Walker and Company, 2007), 165-175.

38. Robert H. van Gent, "A History of the International Date Line," accessed January 13, 2019. Retrieved from https://bit.ly/2n01OhC.

39. John Davies and C. W. Newbury, The History of the Tahitian Mission, 17991830: With Supplementary Papers from the Correspondence of the Missionaries (Cambridge: Published for the Hakluyt Society at the University Press, 1961), 307. 
accounts use Friday, one is from Lieutenant Shillibeer of the Briton and the other is from Jenny, the Tahitian and ex-consort of mutineers John Adams and Isaac Martin. Secondary sources often name only Thursday, ${ }^{40}$ while others mention a name change from Thursday to Friday or back again to Thursday. Mutineer descendant and Pitcairn historian Rosalind Young (1853-1924) used Thursday throughout her now classic and rare book. ${ }^{41}$ Glynn Christian (b. 1942), another descendant, assigned the original dating error to Fletcher for not accounting for a date line crossing. When Thursday "learned," he promptly changed his name to Friday. ${ }^{42}$ This explanation is insufficient as it ignored the how, when, and where of this calendar error. Lummis purports Friday, but within parentheses "(his name was changed from 'Thursday' when it was discovered that the settlers were a day behind, having lost a day by nearly circumnavigation the world)." 43 Ball states that the name change was from Friday to Thursday. He said this occurred in 1808 during the visit of Mayhew Folger of the Topaz. Spencer Murray from Pitcairn Island: The First 200 Years provides still another explanation for the calendar correction: ${ }^{44}$

It wasn't until 17 September 1814 (a true date taking into account the day-change calculation) and the arrival of two British ships at Pitcairn, HMS Briton and HMS Tagus, commanded respectively by Sir Thomas Staines and Philip Pipon, that the calendar error was explained to the islanders. Fletcher's eldest son, named Thursday October Christian after the day and month of his birth in 1790, promptly changed his name to Friday (although he continued to be called Thursday by his fellows and named one of his sons Thursday as well). By proper reckoning, however, he should have been called Wednesday!

Wahlroos and Kirk agree that had there been an unaccounted eastward crossing of the "date line," a correct name change would be to Wednesday as stated in the preceding quote from Spencer Murray. ${ }^{45}$ An eastward crossing of the date line results in a one-day subtraction from the calendar, so Thursday would become Wednesday (Figure 1).

\section{Discussion}

That there was a name change seems reasonable given eyewitness accounts from Lieutenant Shillibeer and two from Jenny, an original settler on Pitcairn

40. Alexander McKee, H.M.S. Bounty (New York: Morrow, 1962).

41. Young, Mutiny of the Bounty, 111.

42. Christian, Fragile Paradise, 337.

43. Lummis, Life and death in Eden, 181.

44. Murray, Pitcairn Island: The First 2000 Years, 50.

45. Wahlroos, Mutiny and Romance in the South Seas, 325; Kirk, Pitcairn Island, 49. 
Island for three decades. Although Shillibeer of the Briton (1814) did not leave the ship, he had the opportunity to meet at least two of the islanders. On encountering McCoy, a mutineer's son, Shillibeer asked him whether he knew Fletcher Christian. McCoy responded, "Oh yes...his son is in the boat there coming up, his name is Friday Fletcher October Christian." 46 The second usage of Friday was from Jenny, someone who would have known. Jenny was the only consort who left Pitcairn to return circuitously to Tahiti. There she gave two interviews with one appearing in the Sydney Gazette and other surfacing in the United Service Journal and Naval and Military Magazine, and later reprinted in Appendix E in Bligh and Christian's The Bounty Mutiny. ${ }^{47}$ In the interview appearing in the Sydney Gazette, she mentions the birth of Fletcher Christian's son, Friday, and his marriage to Teraura. In Jenny's interview published in the United Service Journal and Naval and Military Magazine, she made a fleeting comment about Friday's birth and baptism on the island by William Brown. Her reference to Friday stimulated the editor to add the footnote, "This differs from all other accounts. His Name, according to Sir T. Staines and Capt. Folger, is Thursday October Christian." 48 This is a conundrum. Why Friday? Jenny's mention of Friday does give some credence that there is some truth to a name change. How is this possible? Since she left with Captain Reynolds of the American ship Sultan in 1817 her contact spans from 1790 to $1817 .{ }^{49}$

Thursday appears several times in the Pitcairn Island Register Book, however, Friday does not occur. The change from Thursday to Friday gained usage in the aftermath of Captain Mayhew Folger's visit sailing on the American whaler, Topaz in 1808. However, there is no direct evidence, other than circumstantially, to substantiate that Folger initiated the calendar change. During the Tagus and Briton's visit in 1814, Lieutenant Shillibeer recorded Friday, and while the two English captains, Pipon and Staines record Thursday. Thereafter, Thursday gained prominence with the name surfacing on a list of residents complied during the Elizabeth's visit in 1819, ${ }^{50}$ and on a list of passengers sailing on the Lucy Anne to Tahiti in 1831. His use of Thursday for a son born in 1820 circumstantially supports Thursday over Friday. ${ }^{51}$ Finally, the Register records his death 21 April 1831 as Thursday October

46. Shillibeer, A Narrative of the Briton's Voyage, 82.

47. "Account of the Mutineers of the Ship Bounty, and their Descendants at Pitcairn's Island," Sydney Gazette (17 July 1819), 3; "Jenny's Story," The United Service Journal and Naval and Military Magazine, (London, 1829) Part II, 589-593 as reprinted in "Appendix E" of Bligh and Christian's The Bounty Mutiny, 228-234.

48. Bligh and Christian, The Bounty Mutiny, 231.

49. Herbert Ford, Pitcairn: Port of Call (Angwin, CA: Hawser Titles, 1996).

50. "Extract from the Journal of Captain Henry King of the Elizabeth," 388.

51. Thursday October Christian the II appeared in the Pitcairn Island Register Book and manifest from the Lucy Anne, see footnotes 5 (Lucus) and 28 (Brodie), respectively. 
Christian. Still some doubt exists, with Shapiro, Ball, Dening, and Frost, all secondary sources, claiming Friday came first. Most eyewitness accounts refer to the first born as Thursday, including Staines, Pipon, Bechervaise, the Lucy Anne's log, and the Pitcairn Island Register Book.

The calendar change probably originated during the short visit by Captain Folger in 1808 of the American whaler Topaz. Folger had crossed into the Pacific via the Cape of Good Hope and the Indian Ocean, and thought it Friday as opposed to Pitcairn's Thursday. Bligh, following custom of that era, ignored correcting dates on crossing the $180^{\circ}$ meridian. ${ }^{52}$ Further, during the 1700s and 1800s British ship logs were kept according to nautical time; this adds another dimension confound factor. A nautical day begins at noon today and ends at noon tomorrow, but is given tomorrow's date. ${ }^{53}$ On Friday, 19 September 1788 (nautical calendar), the Bounty was located at $178.7^{\circ}$ west longitude; and on Saturday, 20 September 1788, the ship had sailed across the $180^{\circ}$ meridian to 179.8 east longitude. Under the civil calendar, this same event began noon on Thursday, September 18, and continued to noon on Friday, September 19. Had Thursday October Christian been born at sea, this might have been another trifling point of confusion. Fortunately, Jenny, a former consort and eyewitness, said William Brown baptized the child on Pitcairn Island. ${ }^{54}$ The mutineers would have converted from nautical to civil time sometime between taking the ship and settling on Pitcairn Island.

While the Bounty ventured close the $180^{\circ}$ meridian after the mutiny, Maude's reconstruction (mapping) has the ship venturing just east of the $180^{\text {th }}$ meridian $\left(178^{\circ} \mathrm{E}\right)$, but not crossing, near Vatoa or Ono-i-Lau (Fiji). ${ }^{55}$ This Maude gleaned from two eyewitnesses; one by the Bounty's boatswain's mate Morrison, and the other account from Jenny, previously mentioned.

The editors of the Quarterly Review mentioned being "favoured with some further particulars," presumably from Captain Pipon, added comments on Pitcairn's calendar confusion.

This was occasioned by the Bounty having proceeded thither by the eastern route, and our frigates having gone to the westward; and the Topaz found them right according to his own reckoning, she having also approached the island from the eastward. Every ship from Europe proceeding to Pitcairn's Island round the cape of Good Hope will find them a day later, - as those who approach then

52. Neither did Captain Cook correct for crossing the dateline on his voyages across the $180^{\text {th }}$ meridian. See James Cook, The Journals of Captain Cook (London, Penguin Classics, 2003), 68-73, 310.

53. Henry Harries, "Nautical Time," Mariner's Mirror 14, no. 4 (1928): 364-370.

54. William Brown, mutineer, was a gardener assigned to the Bounty; Bligh and Christian, The Bounty Mutiny, 231.

55. Henry Evans Maude, "In Search of a Home: From the Mutiny to Pitcairn Island (1789-1790)," The Journal of the Polynesian Society 67, no. 2 (1958): 126. 
round Cape Horn, a day in advance, as the case with Captain Folger, and the Captains Sir T. Staines and Pipon. ${ }^{66}$

It is interesting that only after Folger's 1808 visit does Thursday change his name to Friday, and this was substantiated in McCoy's introduction of "Friday October Christian" to Lieutenant Shillibeer in 1814. In assigning blame, credit Folger for adding a day to the island's calendar. Pipon emphatically blamed the "American Captain of the Topaz," Mayhew Folger for misleading the islanders.

Captains Staines and Pipon on their visit in 1814 realized that the islanders' needed to subtract one day from their calendar. Pipon placed blame on Captain Folger during his brief 1808 visit, he wrote that:

On our arrival here we found that John Adams was mistaken in the day of the Week \& Month: he considered it to be Sunday the 18 Sept. 1814 \& to his Credit they were keeping the Sabbath very properly making it a day of rest \& prayer: whereas it was Saturday the $17^{\text {th }}$. By his account he had been misled by the American Captain of the Topaz when she touched here, \& it was pleasing to observe, that they made the Sabbath day a day of rest, \& set it apart for particular prayer \& devotion. ${ }^{57}$

It is ironic twist that from about 1808 to 1814 that these future Seventh Day Adventists were worshiping on Saturday. Interestingly, when the Pitcairners changed from Church of England en masse to Seventh-day Adventism in 1887, Pitcairn's Sabbath changed again from Sunday to Saturday.

\section{Conclusion}

Thursday October Christian was born in 1790 well east of the $180^{\circ}$ meridian on Pitcairn Island. Bligh's Bounty did not correct for an eastward crossing of the $180^{\circ}$ meridian in 1788. Supposing the IDL existed in 1789, in an eastward crossing, Thursday becomes Wednesday and not Friday. When Folger crossed into the Pacific via the Cape of Good Hope in 1808, he erroneously thought to advance the Pitcairn calendar one day; hence, a Thursday became a faux Friday, and so forth (i.e., Saturday became a faux Sunday). During 1814, Staines and Pipon learned that the Pitcairners were one day ahead on their calendar! With Staines and Pipon alerting the islanders of this predicament, Friday changed his name back to Thursday, and John Adams, the last surviving mutineer, returned to keeping the Sabbath on Sunday instead of Saturday until the adoption of Seventh-Day Adventism

56. Delano, Narrative of Voyages, 132.

57. Pipon, Capt Pipon's Narrative of the State Mutineers, page 11 of transcription. 
when it ironically returned to Saturday.

Thursday October Christian is the name given to the first-born son of Fletcher Christian. That he might have changed his name to Friday after the arrival of Mayhew Folger in 1808, and later reverted to Thursday with a calendric correction suggested by Captains Staines and Pipon in 1814 is probable. Two of the eyewitness accounts support that a name change occurred, at least temporarily. How else does one account for Shillibeer's sketch titled Friday Fletcher October Christian, McCoy's introduction of "Friday" to Shillibeer, and Jenny reference to a son born to Fletcher Christian as Friday. Since Jenny left Pitcairn Island in 1817 she would have been around during the name change, and that might have remained the most vivid in her memory. However, after 1814, the name Thursday October Christian claims dominance; he even names a son born in 1820 Thursday October Christian.

Notwithstanding the Thursday or Friday conundrum, the first-born child of the mutiny on the Bounty, by all accounts, was an honest, hospitable, and thoughtful individual. During his lifetime of forty years (1790 to 1831), forty ships called on Pitcairn Island. ${ }^{58}$ These ships started arriving during his eighteenth year and continued until his final departure on the transport Lucy Anne to Tahiti in 1831. This ordinary person, while living on an exceptionally remote island, managed to interact with American and British seafarers including sealers, whalers, merchants and traders, and naval officers. Today his legacy lives on among the Pitcairn Islanders and Bounty enthusiasts around the world. His memory is venerated Norfolk Island and Pitcairn Islands stamps. Even here, the enigma lives on with Norfolk Island using Thursday October Christian and Pitcairn Islands using Friday October Christian for their respective stamp issues.

\section{Acknowledgement}

The author is grateful for a Nancy and Jim Tiller Endowment Award that allowed travel to the Pitcairn Island Study Center at Pacific Union College, Angwin, California.

58. Shapiro, The Heritage of the Bounty, 1936, 107; Ford, Pitcairn: Port of Call, 3-16. 


\section{Bibliography}

"Account of the Mutineers of the Ship Bounty, and their Descendants at Pitcairn's Island." Sydney Gazette (17 July 1819).

Albert, Donald Patrick. "Charles Christian and His Contributions to Pitcairn History." The Pitcairn Log 46, no. 2 (April 2019): 8-10.

"Did or Could Seabirds 'Halo' Pitcairn Island for Fletcher Christian?." Terrae Incognitae 50, no. 2 (2018): 99-114.

Alexander, Caroline. The Bounty: The True Story of the Mutiny on the Bounty. New York: Viking, 2003.

Ball, Ian M. Pitcairn: Children of Mutiny. Boston: Little Brown, 1973.

Bechervaise, John. Thirty-Six Years of a Seafaring Life. Portsea, England: W. Woodward, 1839.

Beechey, Frederick W. Narrative of A Voyage To The Pacific And Beering's Strait, To Co-Operate With The Polar Expeditions: Performed In His Majesty's Ship Blossom, Under The Command Of Captain F. W. Beechey, R. N. In The Years 1825, 26, 27, 28, vol. 1. London: Henry Colburn and Richard Bentley, 1831.

Bergreen, Laurence. Over the Edge of the World: Magellan's Terrifying Circumnavigation of the Globe. New York: Morrow, 2003.

Bligh, William, and Edward Christian. The Bounty Mutiny. New York: Penguin Books, 2001.

Brodie, Walter. Pitcairn's Island, and the Islanders in 1850. London: Whittaker \& Co., 1851.

Christian, Glynn. Fragile Paradise: The Discovery of Fletcher Christian, Bounty Mutineer. United States: Bounty Books, 2005.

Cook, James. The Journals of Captain Cook. London, Penguin Classics, 2003.

Davies, John, and C. W. Newbury. The History of the Tahitian Mission, 17991830: With Supplementary Papers from the Correspondence of the Missionaries. Cambridge: Published for the Hakluyt Society at the University Press, 1961.

Delano, Amasa. A Narrative of Voyages and Travels, in the Northern and Southern Hemispheres: Comprising Three Voyages Round the World, Together with a Voyage of Survey and Discovery, in the Pacific Ocean and Oriental Islands. Boston: Printed by E. G. House, for the author, 1817.

Dening, Greg. Mr Bligh's Bad Language: Passion, Power, and Theatre on the Bounty. Cambridge, England: Cambridge University Press, 1992.

"Extract from the Journal of Captain Henry King of the Elizabeth." The Edinburgh Philosophical Journal 3, no. 6 (Oct. 1820): 380-388.

Ford, Herbert. Pitcairn: Port of Call. Angwin, CA: Hawser Titles, 1996.

Frost, Alan. Mutiny, Mayhem, Methodology: Bounty's Enigmatic Voyage. Sydney: Sydney University Press, 2018), 142-143.

Harries, Henry. "Nautical Time." Mariner's Mirror 14, no. 4 (1928): 364-370. 
Hawkesworth, John, Joseph Banks, James Cook, Philip Carteret, John Samuel Wallis, and John Byron. An Account of the Voyages Undertaken by the Order of His Present Majesty for Making Discoveries in the Southern Hemisphere, and Successively Performed by Commodore Byron, Captain Wallis, Captain Carteret, and Captain Cook, in the Dolphin, the Swallow, and the Endeavour: Drawn Up from the Journals Which Were Kept by the Several Commanders, and from the Papers of Joseph Banks, Esq. London: Printed for W. Strahan and T. Cadell in the Strand, 1773.

Hough, Richard. Captain Bligh \& Mr. Christian: The Men and the Mutiny. New York, E.P.: Dutton, 1973.

Guide to Pitcairn. Adamstown, Pitcairn Island: Government of Pitcairn Island's Tourism Department, 2013.

Kirk, Robert. Pitcairn Island, the Bounty Mutineers and Their Descendants: A History. Jefferson, N.C.: McFarland \& Co, 2008.

Lucas, Charles Prestwood. The Pitcairn Island Register Book. London: Society for Promoting Christian Knowledge, 1929.

Lummis, Trevor. Life and Death in Eden: Pitcairn Island and the Bounty Mutineers. London: Phoenix, 2000.

Maude, Henry Evans. "In Search of a Home: From the Mutiny to Pitcairn Island (1789-1790)." The Journal of the Polynesian Society 67, no. 2 (1958): 126.

McKee, Alexander. H.M.S. Bounty. New York: Morrow, 1962.

Murray, Spencer. Pitcairn Island: The First 2000 Years. La Canada, CA: Bounty Sagas, 1992.

Pipon, Philip. Capt Pipon's Narrative of the State Mutineers of H. M. Ship Bounty Settled on Pitcairn's Island in the South Sea. Retrieved from https://bit.ly/211 5TBG.

. "The Descendants of the Bounty's Crew: As First Discovered by the Briton and Tagus Frigates. - From the Unpublished Mss. of the Late Capt. Pipon, R.N." The United Service Journal (1834), Pt. 1: 197.

Shapiro, Harry L. The Heritage of the Bounty: The Story of Pitcairn Through Six Generations. New York: Simon and Schuster, 1936.

Shillibeer, John. A Narrative of the Briton's Voyage to Pitcairn's Island. London: Law and Whittaker, 1817.

Sobel, Dava. Longitude. New York: Walker and Company, 2007.

van Gent, Robert H. "A History of the International Date Line." Accessed January 13, 2019. Retrieved from https://bit.ly/2n01OhC.

Wahlroos, Sven. Mutiny and Romance in the South Seas: A Companion to the Bounty Adventure. iUniverse.com, Inc., 2001.

Young, Rosalind Amelia. Mutiny of the Bounty and Story of Pitcairn Island, 17901894. Oakland: Pacific Press Pub. Co., 1894. 
